\title{
DETERMINATION OF LETHAL AND SUB-LETHAL CONCENTRATIONS OF ARSENIC IN CYPRINUS CARPIO
}

\author{
MALIK, R. ${ }^{*}$ - NAEEM, M. \\ Institute of Pure and Applied Biology, Bahauddin Zakariya University, Multan, Pakistan \\ *Corresponding authors \\ e-mail: rozinasattar04@gmail.com;drnaeem@bzu.edu.pk
}

(Received 16 $6^{\text {th }}$ Sep 2018; accepted 21 $1^{\text {st }}$ Jan 2020)

\begin{abstract}
The experiment was conducted to determine the lethal and sub-lethal concentrations of arsenic (As) in European carp (Cyprinus carpio L.) at College of Veterinary Sciences, BZU, Bahadur sub Campus Layyah Pakistan. The experimental fish were kept in aquarium and exposed to 5, 10, 15, 20, 25, 30 and $35 \mathrm{mg} / \mathrm{L}$ concentrations of As in laboratory. One group was considered to be the control where fish were not exposed to As. In each concentration, 10 fish were kept for a 96-h exposure period. There were five replications in each group. Dead fish were removed regularly from each test aquarium. Collected data of mortality were analyzed by using the Probit analysis in order to determine the $96-\mathrm{LCC}_{50}$ of As on Cyprinus carpio with $P \leq 0.05$ probability level. Hepatosomatic index (HSI), gonadosomatic index (GSI) and intestinalsomatic index (ISI) were calculated based on weight of the body and weight of the respective organ of Cyprinus carpio fish. Results indicated that 96-h $\mathrm{LC}_{50}$ value of As in Cyprinus carpio was $25 \mathrm{mg} \mathrm{L}^{-1}$. Sub lethal concentrations were 5.0, 2.5, 1.65 and $1.25 \mathrm{mg} \mathrm{L}^{-1}$ that were determined by taking $1 / 5^{\text {th }}, 1 / 10^{\text {th }}, 1 / 15^{\text {th }}$ and $1 / 20^{\text {th }}$ of $\mathrm{LC}_{50}$. Likewise, increasing concentration of As significantly enhanced the value of HSI and reduced the value of GSI and ISI of Cyprinus carpio species. This study concluded that $25 \mathrm{mg} \mathrm{L}^{-1} \mathrm{As}$ was found to be $50 \%$ lethal concentration for Cyprinus carpio species.
\end{abstract}

Keywords: acute toxicity, hepatosomatic, gonadosomatic, intestinalsomatic, $\mathrm{LC}_{50}$

\section{Introduction}

Heavy metals are serious environmental pollutants effecting human beings differential injuriousness and aquatic organisms due to their high toxicity (Yang et al., 2014; Javed, 2015). To perform various physiological functions vital metals are required by the living organisms but beyond definite concentrations they may become hazardous to the organisms due to generation of free radicals leading to oxidative stress (Merciai et al., 2014). The important factors influencing the differential injuriousness of metallic ions are metal specific, including the mode of action and the solubility of the metal along with the physicochemical properties of the test medium (Naz and Javed, 2012; Gupta and Karthikeyan, 2016).

In different region of the world many types of contaminants are spread such as arsenic (As) (Flora et al., 2005; Shrivastava et al., 2015). Naturally As is present in the water in different chemical species and different oxidation states. The As known as a toxic trace element. The arsenite $\left(\mathrm{AsO}_{3}{ }^{3-}\right)$ or arsenate $\left(\mathrm{AsO}_{4}{ }^{-3}\right)$ are inorganic forms of this heavy metal and commonly its abundant forms are inorganic in the nature (Akter et al., 2005; Pedlar et al., 2002). The effect of As is more prominent when it interfere in accumulation, concentration, excretion and the gastrointestinal tract, skin, kidney and liver. As disturbs the biochemical, haematological and most important ion-regulatory factors of organisms and mainly fish present in the aquatic media, and variations of previous factors can be beneficial in environmental bio-monitoring from the contamination of As (Lavanya et al., 2011). For evaluating the effects of environmental pollution on aquatic ecosystems fish are choice of an organism (Gaim et al., 2015). As- 
contaminated food by a fish intake through their gills, skin, and they are continuously exposed to it. Fishes are good indicators of As toxicity, they have long sentinels and used for biomonitoring of aquatic life and contaminants that is present im the water (Tisler and Zagorc-Koncan, 2002). Lethal toxicity of toxicant can be tested through the determination of $\mathrm{LC}_{50}$ value which is the most reliable for assessing the adverse effect on fish (Kumari et al., 2017). To make or establish the biomarkers of exposure fishes have good power of models as to study the toxicogenomics fishes are perfect organisms to work (Das et al., 2012). To reduce the hazardous forms of As in aquatic life fishes are best as they have different mechanisms for biotransformation (Bears et al., 2006). When the concentration of As increases in an aquatic ecosystem, than it affects various physiological systems like growth, reproduction, immune function, gene expression, histopathology and enzyme activities in the body of fish (Datta et al., 2009). It will negative for the health of humans if As-contaminated fish intake by the humans (Kar et al., 2011). The As involved in a series of molecular events like iron homeostasis, oxidative stress, carcinogenesis and lipid metabolism disorder (Xu et al., 2013). The As contamination is linked with the formation of Reactive oxygen species (ROS) causes severe injury and damage to the biological systems of organisms that is result of the As contamination (Patlolla and Tchounwou, 2005). The bioindicator of contaminant exposure is basically known as hepatosomatic index (HSI) (Sadekarpawar and Parikh, 2013). The changing in size of liver hypertrophy (an increase in size) and hyperplasia (an increase in number) is the result of detoxification of As contamination (Solé et al., 2010). The Study evaluate the relative liver size of fishes from contaminated places and disturbed locations also utilize the HSI, that expresses liver size in the form of percentage of the total body weight (Sadekarpawar and Parikh, 2013). Structural information and more functional like health and gonadal maturation status is supply by gonadosomatic index (GSI) which is also a bioindicator. The majority of the species go through the reproductive cycle and, commonly, difference in the gonadal size is observed in the cycle (Sadekarpawar and Parikh, 2013). The gonadal weight of the body in percentage used for defining the reproductive maturity and replies of environmental dynamics (e.g., seasonal changes) similarly, the exogenous stress also (e.g., exposition to contaminants). The gonad alterations like reduction of GSI and morphological changes are caused by the result of several environmental pollutants it is significative evidence (Sakamoto et al., 2003). Keeping in view the present issues connecting to freshwater fisheries in Pakistan the current research work was carried out to determine the lethal and sub lethal concentration of As to $C$. carpio that will help in the expansion of proper strategies for sustainable conservation of the fish.

\section{Materials and methods}

European carp (Cyprinus carpio L.) 400 fish $(10 \pm 0.5 \mathrm{~cm}$ length and $60 \pm 5 \mathrm{~g}$ weight $)$ were collected from fish nursery Karor Lali Ehsan Layyah Pakistan, acclimatized in aquaria for 15 days under laboratory conditions at College of Veterinary Sciences, BZU, Bahadur sub Campus Layyah Pakistan. The aquaria were continuously aerated through stone diffusers connected to a mechanical air compressor. Water temperature was $25 \pm 2{ }^{\circ} \mathrm{C}$ and $\mathrm{pH}$ was maintained between 6.6 and 7.5. The fish were fed twice daily alternately with egg, goat liver and raw brine shrimp pellets. The experimental fish were exposed to different concentrations of arsenic viz: 5, 10, 15, 20, 25, 30 and $35 \mathrm{mg} / \mathrm{L}$. One group was considered as a control where fish were not exposed to As. The 10 fish for 
each concentration of As test were used. In the experimental aquaria water was replaced daily with fresh treatment of As. Five replicates for each concentration of arsenic was arranged under Complete Randomized Design (CRD). The experimental treatments were 0 (control), 5.0, 10.0, 15.0, 20.0, 25.0, 30.0 and $35.0 \mathrm{mg} / \mathrm{L}$ arsenic. Following parameters were studies during the course of study.

\section{Determination of $L_{50}$ arsenic concentration}

Ten fish samples were transferred to each aquarium and exposed to different concentrations of As $(5,10,15,20,25,30$ and $35 \mathrm{mg} / \mathrm{L})$ from sodium arsenite $\left(\mathrm{NaAsO}_{2}\right)$ was used as arsenic source. In all cases, control groups of fish were maintained. This trial was carried out for a period of $96 \mathrm{~h} \mathrm{LC} 50$. The mortality of the fish was recorded at $96 \mathrm{~h}$ of exposure. The effect of each concentration was tested at least in duplicate to verify reproducibility. The data were obtained in course of the investigation was analyzed statistically to see whether there is any influence of different treatments concentrations on the mortality of fish.

\section{Sub-lethal concentration of arsenic}

The concentrations of arsenic viz: 5, 10, 15, 20, 25, 30 and $35 \mathrm{mg} / \mathrm{L}$ were maintained in each treatment. Control group of fish was maintained without application of As. Sub lethal concentrations were determined by taking $1 / 5^{\text {th }}, 1 / 10^{\text {th }}, 1 / 15^{\text {th }}$ and $1 / 20^{\text {th }}$ of $\mathrm{LC}_{50}$ (Abdel-Hameid, 2009).

\section{Length and weight}

Samples of fish were removed from the aquaria of respective treatments. All samples were washed with distilled water, and transferred to the laboratory. Length of the fish was measured with the help of measuring tap and weight was noted with electronic balance (Digital Bench Scale - QM7264, Electric Burst Australia Pty Ltd).

\section{Somatic indices}

After the period of exposure fishes were removed and washed with freshwater. Control as well as treated groups were anesthetized by immersion in $50 \mathrm{mg} / \mathrm{L}$ tricaine methane sulphonate solution for 5-10 min before they were killed by decapitation and weighed; blood was allowed to drain and dissected to take out organs. Hence the liver, gonads and intestines weight was taken for the Hepatosomatic index (HSI), Gonadosomatic index (GSI) and Intestinal somatic index (ISI). The indices were calculated according to the following formula Parmeswaran (1974):

$$
\begin{gathered}
\text { HSI }=(\text { Liver weight }(\mathrm{g}) / \text { Fish weight }(\mathrm{g})) \times 100 \\
\text { GSI }=(\text { Gonad weight }(\mathrm{g}) / \text { Fish weight }(\mathrm{g})) \times 100 \\
\text { ISI }=(\text { Intestines weight }(\mathrm{g}) / \text { Fish weight }(\mathrm{g})) \times 100
\end{gathered}
$$

\section{Statistical analysis}

The statistical analysis of this work was done using STATISTIX 8.1. The data of this work was presented as means \pm standard deviation. Pair wise comparison was done 
between control and experimental groups by employing Duncan multiple variance test to resolve the statistical significance of the difference between the groups (Pipkin, 1984).

\section{Results}

Analyzed data reveal that mortality of $C$. carpio was increased by increasing the concentration of As. The $50 \%$ mortality was recorded at $25 \mathrm{mg} \mathrm{L}^{-1}$ As concentration while it caused $60 \%$ and $80 \%$ mortality at 30 and $35 \mathrm{mg} \mathrm{L}^{-1}$ respectively (Table 1). Whereas; other As concentrations 5, 10, 15 and $20 \mathrm{mg} \mathrm{L}^{-1}$ caused the 10, 30 and $40 \%$ morality in C. carpio (Table 1). These lethal concentrations of As to tested fish species was determined by the mean value of $96 \mathrm{~h} \mathrm{LC}_{50}$ and with $95 \%$ confidence interval significant $P<0.05$. The other concentrations of As were observed below the concentration of $25 \mathrm{mg} \mathrm{L}^{-1}$. The upper and lower $95 \%$ confidence limits. Thus, As rated as highly toxic to $C$. carpio. Non-significant mortality was observed in control and $5 \mathrm{mg}$ $\mathrm{L}^{-1}$ during the experimental periods (Table 1 ).

Table 1. Effect of different concentration of arsenic on mortality of Cyprinus carpio

\begin{tabular}{c|c|c|c|c}
\hline Arsenic conc. $\left(\mathbf{m g ~ L}^{\mathbf{- 1}}\right)$ & Log conc. & $\begin{array}{c}\text { Number of fish } \\
\text { alive out of fifty }\end{array}$ & Mortality $\%$ & Probit kill \\
\hline 0.0 (control) & -- & 50 & 0 & -- \\
5.0 & 0.70 & 50 & 0 & -- \\
10.0 & 1.00 & 45 & 10 & 3.73 \\
15.0 & 1.18 & 35 & 30 & 4.48 \\
20.0 & 1.30 & 35 & 30 & 4.48 \\
25.0 & 1.40 & 25 & 50 & 5.00 \\
30.0 & 1.40 & 20 & 60 & 5.25 \\
35.0 & 1.48 & 10 & 80 & 5.84 \\
\hline
\end{tabular}

The various concentrations of As showed significant difference in mean length and weight of $C$. carpio. Significantly higher mean length and weight was gained in control group and that differences were not statistically significant where As was applied at the rate 5 and $10 \mathrm{mg} \mathrm{L}^{-1}$ respectively (Fig. 1). After that there was gradual decrease in mean length and weight with increasing the concentration of As (Figs. 1 and 2). Results indicated that value of HSI decreased significantly with increasing the level of As concentrations. Highest value of HSI was recorded in control treatment where As was not applied which was not statistically significant with lowest concentration $\left(5 \mathrm{mg} \mathrm{L}^{-1}\right)$ of As (Fig. 3). It was found that there is gradual decrease in the value of HSI. Whereas; lowest value of HSI was measured at the highest concentration of As (Fig. 3). The GSI value showed significant difference among all As concentration. Significantly higher value of GSI was recorded in the control treatment that there were not statistically significant at 5 and $10 \mathrm{mg} \mathrm{L}^{-1}$ respectively (Fig. 4). After that there was gradual decrease in the value of GSI with increasing the concentration of As. In addition, lowest value of GSI was observed in the group where As was applied $35 \mathrm{mg} \mathrm{L}^{-1}$ while differences were not statistically significant to the group $7^{\text {th }}$ where As was applied $30 \mathrm{mg} \mathrm{L}^{-1}$ (Fig. 4). The value of ISI significantly decreased in fish subjected to As levels. Higher value of ISI was determined in the fish in control group that there were no significant differences where 
fish was exposed to As level of 5 and $10 \mathrm{mg} \mathrm{L}^{-1}$ respectively. After that there was gradual decrease in the value of ISI with increasing the concentration of As (Fig. 5). In addition, lowest value of ISI was observed at $35.0 \mathrm{mg} \mathrm{L}^{-1}$ As concentration which was not statistically different to $30 \mathrm{mg}-\mathrm{L}$ As concentration (Fig. 5).

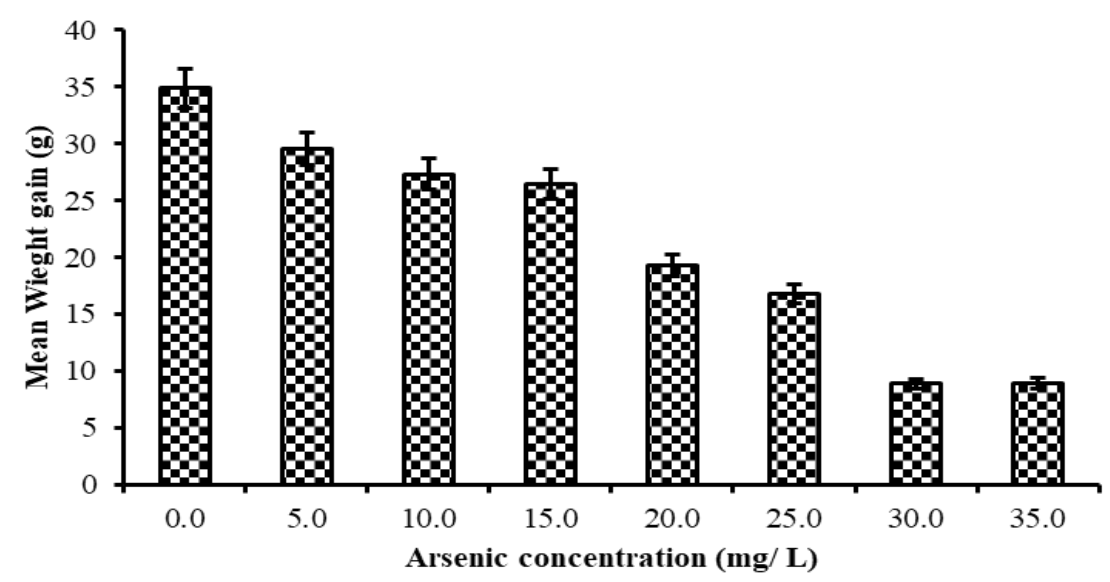

Figure 1. Effect of different concentration of arsenic on mean weight gain of Cyprinus carpio

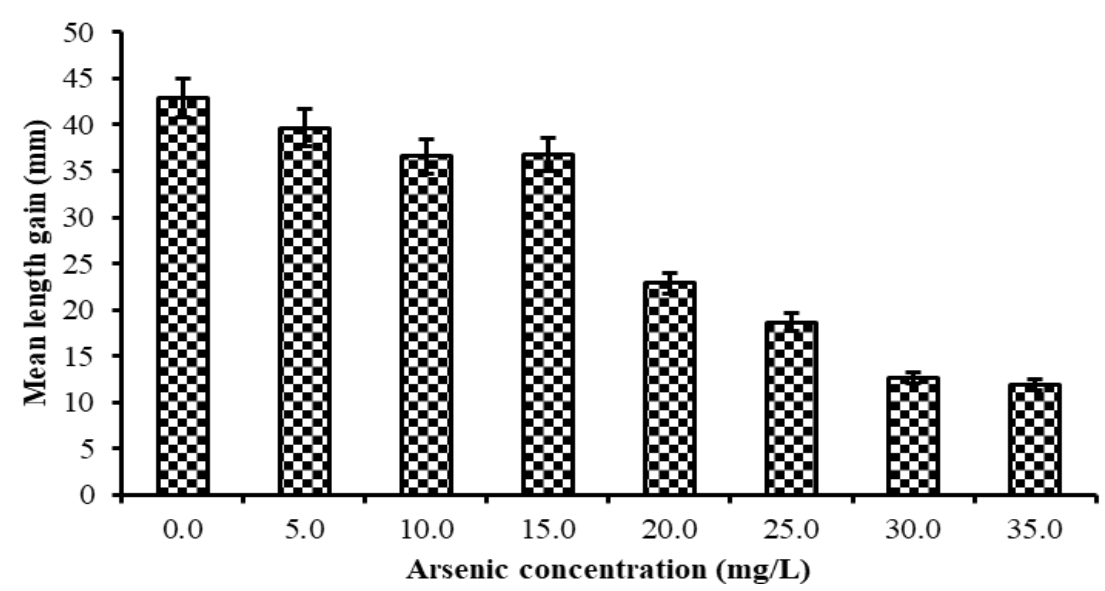

Figure 2. Effect of different concentration of arsenic on mean length gain of Cyprinus carpio

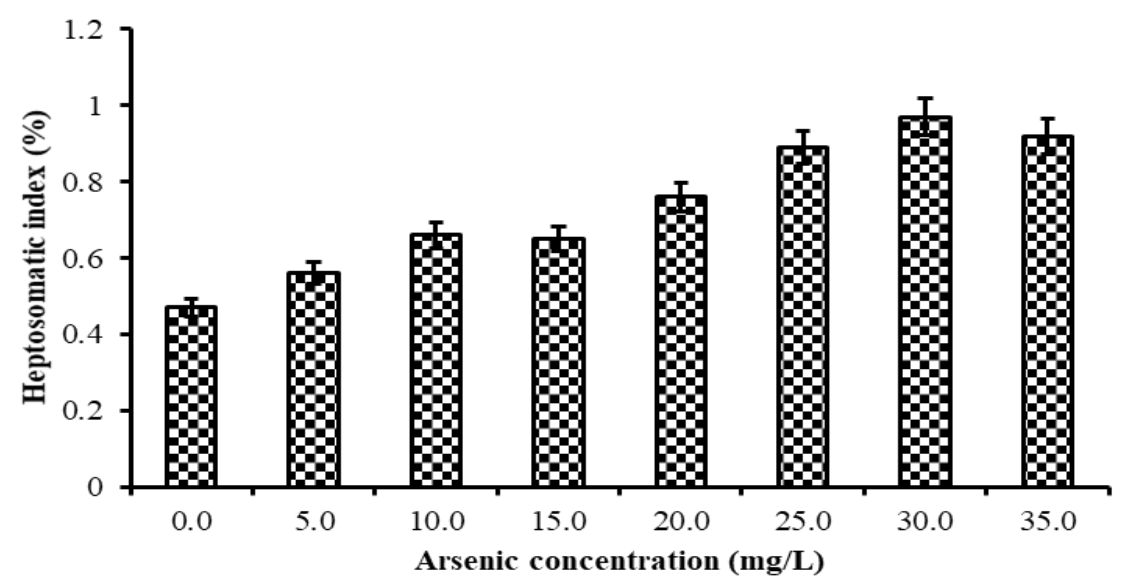

Figure 3. Effect of different concentration of arsenic on heptosomatic index of Cyprinus carpio 


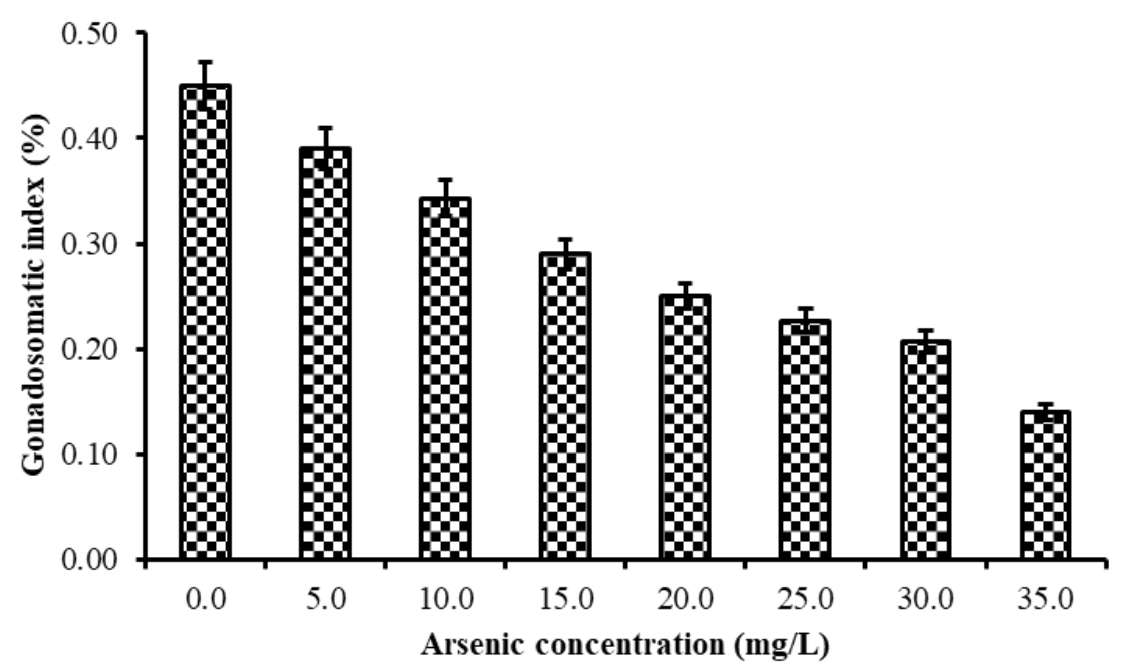

Figure 4. Effect of different concentration of arsenic on gonadosomatic index of Cyprinus carpio

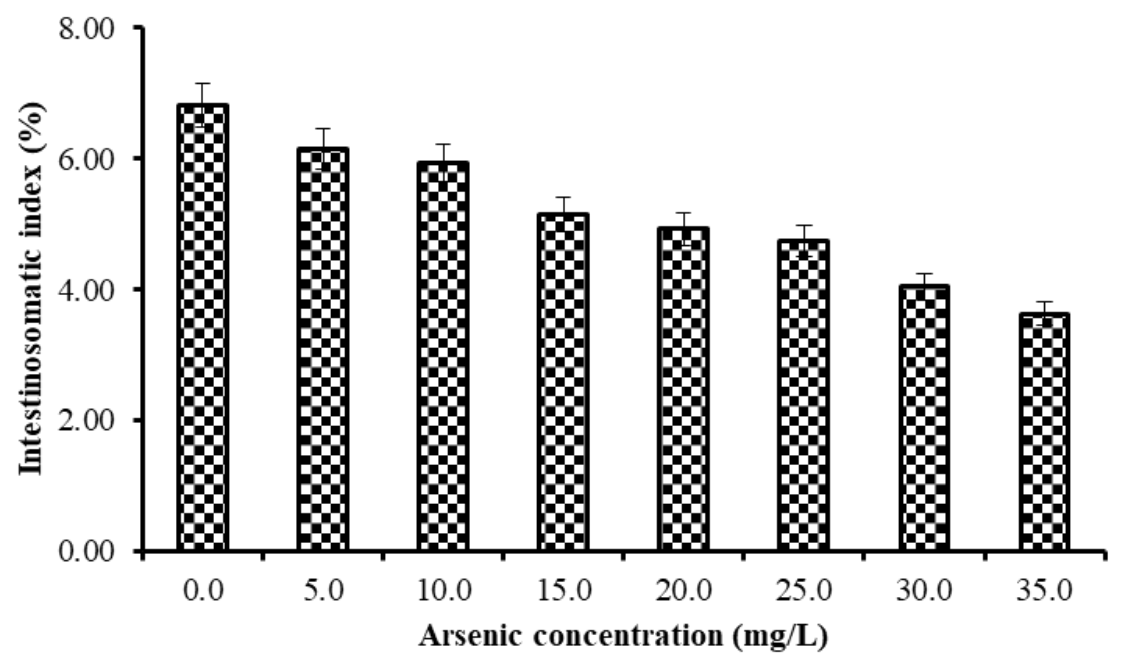

Figure 5. Effect of different concentration of arsenic on intestinosomatic index of Cyprinus carpio

\section{Discussion}

Instant and delayed toxic effects that occur in fish are the results of lethal toxicity. This delayed effect results in discoloration of skin and death of fish occurs ultimately (Abdullah and Javed, 2006). For 96-h LC 50 determination, species-specific factor like fish sensitivity towards particular metals is important. In current study, the mortality of Cyprinus carpio increased gradually with increasing the level of As (Fig. 6). Pandey et al. (2005) reported the acute toxicity caused by arsenic in Dicentrarchus labrax based on dosage. Morcillo et al. (2015) reported mercuric chloride and malathion toxicity at 96-h time dependent dose in Channa puctatus. The results of our experiment showed that $25 \mathrm{mg} \mathrm{L}^{-1}$ was found to be 96-h LC $\mathrm{LC}_{50}$ and lethal concentrations of As for C. carpio. This indicates the mortality rate which increased with the increase in concentration for a particular time with regular mode of toxicant action at dangerous level due to As 
accumulation ultimately leading to fish death (Reddy et al., 2016). Over the gills fish, a mucus film formed when oxygen culminates hence damage occurs by respiratory epithelium causing mortality. (Das and Sahu, 2005) because gills tissues are main target organ of the fish imposed to As. As exposure to fish cause clogging of gills resulting in breathing anxiety because As damages directly the blood vessels and collapse them in gills (Mondal and Samanta, 2015). Kovendan et al. (2013) determined the $32 \mathrm{mg} \mathrm{L}^{-1}$ Arsenic tri-oxide to the adults' fish $C$. carpio. In another study, $24.5 \mathrm{mg} \mathrm{L}^{-1}$ was found to be 96-h LC $_{50}$ and above that are lethal concentrations of As to Ctenopharyn godonidella (Kousar and Javed, 2014).

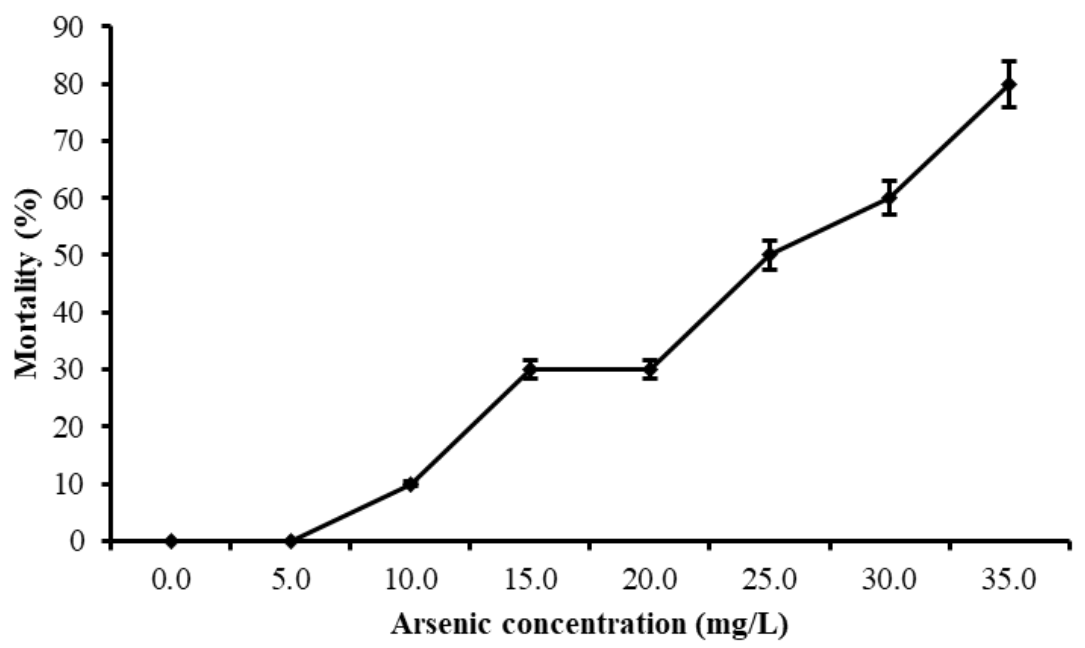

Figure 6. Graphical estimation of 96- $h$ LC $C_{50}$ of arsenic against the Cyprinus carpio

The decreased in mean length and weight due to As exposure in fish can be explained by direct metabolic impacts study or by food chain destitution, both of these actions decreases the fish growth (Eastwood and Couture, 2002). Moreover; higher concentrations of As can change muscle fiber size that ultimately reduced the weight and length of fish (D'Amico et al., 2014). In another study, Begum et al. (2013) exposed fish with As from dose of 7 and $20 \mathrm{mg} / \mathrm{L}$ in $H$. fossilis and concluded that muscles bundles started to degenerate when As is exposed.

Current study indicated that value of hepato-somatic indices increased significantly with increasing the level of As concentrations. Changes in HSI may be considered as a good indicator generally of the tested population of fish (Bolger and Connolly, 1989). HIS increases with the increase in arsenic concentration due to hepatocytes or hyperplasia (Crunkhornet al., 2004). These researches not only favours previous findings about arsenic toxicity but also leads to the suggestion about changes in the liver of $C$. batrachus by sub lethal toxicity of As. (Lu et al., 2001; Chen et al., 2004). Hepatomegaly, reported earlier about fishes by many pollutants (Pait and Nelson, 2003; Barseet al., 2006; Abdel-Hameid, 2007; Datta et al., 2007). In our current study, the value of GSI decreased with increasing concentration of arsenic for Cyprinus carpio. These results are in line with the findings of Yamaguchi et al. (2007) about catfish (Pangasianodon hypophthalamus) exposed to metal water contamination. They reported that As when exposed to the fish, spermatogonia necrosis and sertoli cells vacillation occurs. This study records the ISI value reduction when As exposed. This result is 
almost same who worked to check effects by other pollutants (Abdel-Hameid, 2007; Abdel-Tawwab et al., 2007). It may result in appetite loss and body weight reduction. Many research findings use ISI values as indicator to check physiological responses and changes by less feeding (Abdel-Tawwabet al., 2006, 2007; Abdel-Hameide, 2007).

\section{Conclusion}

Exposure of Cyprinus carpio to various concentration of As induced the harmful effect. Results indicated that 96-h $\mathrm{LC}_{50}$ values of As for Cyprinus carpio was $25 \mathrm{mg} \mathrm{L}^{-1}$. Sub lethal concentrations were determined by taking $1 / 5^{\text {th }}, 1 / 10^{\text {th }}, 1 / 15^{\text {th }}$ and $1 / 20^{\text {th }}$ of $\mathrm{LC}_{50}$ that were found to be 5.0, 2.5, 1.65 and $1.25 \mathrm{mg} \mathrm{L}^{-1}$. Likewise, increasing concentration of As significantly enhanced the value of HSI and reduced the value of GSI and ISI of Cyprinus carpio species.

\section{REFERENCES}

[1] Abdel-Hameid, N. A. H. (2007): Physiological and histological changes induced by phenol exposure in Oreochromis aureus juveniles. - Turk. J. Fish. Aquat. Sci. 7: 131138.

[2] Abdel-Hameid, N. A. H. (2009): A protective effect of calcium carbonate against arsenic toxicity of the Nile catfish, Claria sgariepinus. - Turk. J. Fish. Aquat. Sci. 9: 191-200.

[3] Abdel-Tawwab, M., Khattab, Y. A. E., Ahmad, M. H., Shalaby, A. M. E. (2006): Compensatory growth, feed utilization, whole-body composition and hematological changes in starved juvenile Nile tilapia, Oreochromis niloticus (L.). - J. World Aquat. Soc. 18: 234-239.

[4] Abdel-Tawwab, M., Mousa, M. A. A., Ahmad, M. H., Sakr, S. F. (2007): The use of calcium pre-exposure as a protective agent against environmental copper toxicity for juvenile Nile tilapia, Oreochromis niloticus (L.). - Aqua 264: 236-246.

[5] Abdullah, S., Muhammad, J. (2006): Studies on acute toxicity of metals to the fish, Catlacatla. - Pak. J. Biol. Sci. 9: 1807-1811.

[6] Akter, K. F., Owens, G., Davey, D. E., Naidu, R. (2005): Arsenic speciation and toxicity in biological systems. - Rev. Environ. Contam. Toxicol. 184: 97-149.

[7] Barse, A. V., Chakrabarti, T., Ghosh, T. K., Pal, A. K., Jadhao, S. B. (2006): One-tenth dose of $\mathrm{LC}_{50}$ of 4-tert -butylphenol causes endocrine disruption and metabolic changes in Cyprinus carpio. - Pestic. Biochem. Physiol. 86: 172-179.

[8] Bears, H., Richards, J. G. Schulte, P. M. (2006): Arsenic exposure alters hepatic arsenic species composition and stress-mediated gene expression in the common killifish (Fundulus heteroclitus). - Aquat. Toxicol. 77: 257-266.

[9] Begum, A., Mustafa, A. I., Amin, M. N., Banu, N., Chowdhury, T. R. (2013): Accumulation and histopathological effects of arsenic in tissues of shingi fish (Stinging Catfish) Heteropneustes fossilis. - J. Asiat. Soc. Bangladesh Sci. 39: 221-230.

[10] Bolger, T., Connolly, P. L. (1989): The selection of suitable indices for the measurement and analysis of fish condition. - J. Fish Biol. 34: 171-182.

[11] Chen, H., Li, S. F., Liu, J., Diwan, B. A., Barrett, J. C. Waalkes, M. P. (2004): Chronic inorganic arsenic exposure induces hepatic global and individual gene hypomethylation: implications for arsenic hepatocarcinogenesis. - Carcinogenesis 25: 1779-1786.

[12] Crunkhorn, S. E., Plant, K. E., Gibson, G. G., Kramer, K., Lyon, J., Lord, P. G. Plant, N. J. (2004): Gene expression changes in rat liver following exposure to liver growth agents: role of Kupffer cells in xenobiotic-mediated liver growth. - Biochem. Pharmacol. 67: 107-118. 
[13] D’Amico, A. R., Gibson, A. W., Bain, L. J. (2014): Embryonic arsenic exposure reduces the number of muscle fibers in killifish (Fundulus heteroclitus). - Aquat. Toxicol. 146: 196-204.

[14] Das, S., Sahu, B. (2005): Interaction of $\mathrm{pH}$ with mercuric chloride toxicity to penaeid prawns from a tropical estuary, East Coast of India: enhanced toxicity at low $\mathrm{pH}$. Chemosphere 58: 1241-8.

[15] Das, S., Unni, B., Bhattacharjee, M., Wann, S. B., Rao, P. G. (2012): Toxicological effects of arsenic exposure in a freshwater teleost fish, Channa punctatus. Afr. - J. Biotechnol. 11: 4447-4454.

[16] Datta, S., Saha, D. R., Gosh, D., Majumdar, T., Bhattacharya, S., Mazumder, S. (2007): Sub-lethal concentration of arsenic interferes with the proliferation of hepatocytes and induces in vivo apoptosis in Clarias batrachus L. Comp. - Biochem. Physiol. 145: 339349.

[17] Datta, S., Ghosh, D., Saha, D. R., Bhattacharaya, S., Mazumder, S. (2009): Chronic exposure to low concentration of arsenic is immuno-toxic to fish: role of head kidney macrophages arsenic biomarkers of arsenic toxicity to Clarias batrachus. - Aquat. Toxicol. 92: 86-94.

[18] Eastwood, S., Couture, P. (2002): Seasonal variations in condition and liver metal concentrations of yellow perch (Perca flavescens) from a metal-contaminated environment. - Aquat. Toxicol.58: 43-56.

[19] Flora, S. J., Bhadauria, S. C., Pant, R. K. (2005): Induced blood and brain oxidative stress and its responses to some thiol chelators in rats. - Life Sci.77: 2324-2337.

[20] Gaim, K., Gebru, G., Abba, S. (2015): The effect of arsenic on liver tissue of experimental animals (Fishes and Mice). A review article. - Int. J. Sci. Res. Publ. 5: 1-9.

[21] Gernhofer, M., Pawert, M., Schramm, M., Müller, E., Triebskorn, R. (2001): Ultra structural biomarkers as tools to characterize the health status of fish in contaminated streams. - J. Aquat. Ecosyst. Stress Recovery 8: 241-260.

[22] Gupta, A. D., Karthikeyan, S. (2016): Individual and combined toxic effect of nickel and chromium on biochemical constituents in E. coli using FTIR spectroscopy and Principle component analysis. - Ecotoxicol. Environ. Saf. 130: 289-94.

[23] Javed, M. (2015): Chronic dual exposure (waterborne plus dietary) effects of cadmium, zinc and copper on growth and their bioaccumulation in Cirrhina mrigala. - Pak. Veter. J. 35: 143-146.

[24] Kar, S., Maity, J. P., Jean, J. S., Liu, C. C., Liu, C. W., Bundschuh, J., Lu, H. Y. (2011): Health risks for human intake of aquacultural fish: arsenic bioaccumulation and contamination. - J. Environ. Sci. Health 46: 1266-1273.

[25] Kousar, S., Javed, M. (2014): Heavy metals toxicity and bioaccumulation patterns in the body organs of four fresh water fish species. - Pak. Veter. J. 34: 161-164.

[26] Kovendan, K., Vincent, S., Janarthanan, S., Saravanan, M. (2013): Expression of metallothionein in liver and kidney of freshwater fish Cyprinus carpio var. communis (Linn) exposed to arsenic trioxide. - Am. J. Sci. Ind. Res. 4: 1-10.

[27] Kumari, B., Vikas, K., Amit, K. S., Jawaid, A., Ghosh, A. K., Hanping, W., DeBoeck, G. (2017): Toxicology of arsenic in fish and aquatic systems. - Environ. Chem. Let.15: 4364.

[28] Lavanya, S., Ramesh, M., Kavitha, C., Malarvizhi., A. (2011): Hematological, biochemical and ionoregulatory responses of Indian major carp Catla catla during chronic sublethal exposure to inorganic arsenic. - Chemosphere 82: 977-985.

[29] Lu, T., Liu, J., LeCluyse, E. L., Zhou, Y. S., Cheng, M. L., Waalkes, M. P. (2001): Application of cDNA microarray to the study of arsenic-induced liver diseases in the population of Guizhou, China. - J. Toxicol. Sci. 59: 185-192.

[30] Mondal, K., Samanta, S. (2015): A review on arsenic contamination in fresh water fishes of West Bengal. - J. Global Biosci. 4: 2369-2374. 
[31] Morcillo, P., Cordero, H., Meseguer, J., Esteban, M. A., Cuesta, A. (2015): In vitro immunotoxicological effects of heavy metals on European sea bass Dicentrarchus labrax L. head kidney leucocytes. - Fish Shellfish Immunol. 47: 245-254.

[32] Naz, S., Javed, M. (2012): Acute toxicity of metals mixtures for fish, Catla catla, Labeo rohita and Cirrhina mrigala. - Pak. J. Agric. Sci. 49: 387-391.

[33] Pait, A. S., Nelson, J. O. (2003): Vitellogenesis in male Fundulus heteroclitus (Killifish) induced by selected estrogenic compounds. - Aquat. Toxicol.64: 331-342.

[34] Pandey, S., Parvez, S., Sayeed, I., Haque, R., Bin-Hafeez, B., Raisuddin, S. (2005): Biomarkers of oxidative stress: a comparative study of river Yamuna fish Wallago attu (B1. \& Schn.). - Sci. Total Environ. 309: 105-115.

[35] Parameswaran, S., Selvaraj, C., Radhakrishnan, S. (1974): Observation on the biology of Labeo gonius (Ham.). - Indian J. Fish. 21: 54-75.

[36] Patlolla, A. K., Tchounwou, P. B. (2005): Serum acetyl cholinesterase arsenic a biomarker of arsenic-induced neurotoxicity in Sprague-Dawley rats. - Int. J. Environ. Res. Public Health 2: 80-83.

[37] Pedlar, R. M., Ptashynski, M. D., Evans, R., Klaverkamp, J. F. (2002): Toxicological effects of dietary arsenic exposure in lake whitefish (Coregonus clupeaformis). - Aquat. Toxicol. 57: 167-189.

[38] Pipkin, F. B. (1964): Medical Statistics Made Easy. - Churchill Livingstone, Edinburgh.

[39] Reddy, P. P., Jagadeshwarlu, R., Sunitha, G., Devi. (2016): Determination of lethal concentration (LC50) of copper to Sarotherodon mossambica. - Int. J Fish. Aquat. Stud. 4(1): 172-175.

[40] Sadekarpawar, S., Parikh, P. (2013): Gonadosomatic and Hepatosomatic indices of freshwater fish world. - J. Zool. 8: 110-118.

[41] Sakamoto, K. Q., Nakai, K., Aoto, T., Yokoyama, A., Ushikoshi, R., Hirose, H., Ishizuka, M., Kazusaka, A., Fujita, S. (2003): Cytochrome P450 induction and gonadal status alteration in common carp (Cyprinus carpio) associated with the discharge of dioxin contaminated effluent to the Hikiji River, Kanagawa Prefecture, Japan. - Chemosphere 51: 491-500.

[42] Shrivastava, A., Ghosh, D., Dash, A., Bose, S. (2015): Arsenic contamination in soil and sediment in India: sources, effects, and remediation. - Curr. Pollut. Rep. 1(1): 35-46.

[43] Solé, M., Antó, M., Baena, M., Carrasson, M., CartesJ. E., Maynou, F. (2010): Hepatic biomarkers of xenobiotic metabolism in eighteen marine fish from NW Mediterranean shelf and slope waters in relation to some of their biological and ecological variables. Mar. Environ. Res.70: 181-188.

[44] Tisler, T., Zagorc-Koncan, J. (2002): Acute and chronic toxicity of arsenic to some aquatic organisms. - Bull. Environ. Contam. Toxicol. 69: 4210-29.

[45] Xu, H., Lam, S. H., Shen, Y., Gong, Z. (2013): Genome-wide identification of molecular pathways and biomarkers in response to arsenic exposure in zebrafish liver. - PLoS One 8: 68737.

[46] Yamaguchi, S., Miura, C., Ito, A., Agusa, T., Iwata, H., Tanabe, S., Tuyen, B. C., Miura, T. (2007): Effects of lead, molybdenum, rubidium, arsenic and organochlorines on spermatogenesis in fish: monitoring at Mekong Delta area and in vitro experiment. Aquat. Toxicol. 83: 43-51.

[47] Yang, J., Chen, L., Liu, L., Shi, W., Meng, X. (2014): Comprehensive risk assessment of heavy metals in lake sediment from public parks in Shanghai. - Ecotoxicol. Environ. Saf. 102: 129-135. 